\title{
Opinions of Secondary School Students on the Effects of Disciplinary Regulations and Practices on the Freedom of Thought and Expression ${ }^{*}$
}

Pelin TAŞKIN**

\section{Suggested Citation:}

Taşkin P. (2014). Opinions of Secondary School Students on the Effects of Disciplinary Regulations and Practices on the Freedom of Thought and Expression. Eurasian Journal of Educational Research, 57, 51-72 http://dx.doi.org/10.14689/ejer.2014.57.5

\begin{abstract}
Problem Statement: Disciplinary rules are necessary for students to benefit from education and training activities without any problems or shortcomings in the school environment. Governed by regulation in Turkey, these rules prescribe such penalties as reprimand, short-term suspension, changing of schools, or exclusion from formal education institutions. Conversely, various national and international legal arrangements define children's fundamental rights and freedoms. Students below the age of 18 are also entitled to fundamental rights and freedoms by reason of such legal arrangements. One of these arrangements recognises the freedom of thought and expression. The children's/students' freedom of thought and expression within the school environment, as well as the limitations thereof, are of a disputed nature. In light of such disputes, the problem addressed by the present study concerns the evaluation of the effects of disciplinary regulations and practices on students' freedom of thought and expression in line with students' own opinions.

Purpose of Study: The present study aims to identify how secondary school students consider the freedom of thought and expression within the context of disciplinary regulations and practices.

Methods: The study is a qualitative study designed and implemented in a phenomenological pattern. The sample of the study was composed, in line with the maximum diversity sampling technique, of 15 students from amongst all students enrolled at general public and private secondary
\end{abstract}

\footnotetext{
* The present study is based primarily on the PhD Thesis of Pelin Taşkın at Ankara University, supervised by Prof. Dr. Yasemin Karaman Kepenekci, called 'An Evaluation of Disciplinary Code on Secondary Education Students on the Basis of Fundamental Rights and Freedoms.'

*Dr. Ankara University Faculty of Educational Sciences, 06590, Ankara, Turkey, email:ptaskin@education.ankara.edu.tr
} 
education institutions located in the central districts of the province of Ankara. Fifteen students were interviewed face-to-face in accordance with the semi-structured interview form. The interviews were recorded on paper and made subject to content analysis. The analysis categories (themes) were defined, in parallel with the objective of the study, as the evaluation of disciplinary regulations and practices applied to students in secondary schools within the dimension of the "Freedom of Thought and Expression". The subcategories were identified with the inductive method during the analyses.

Findings and Results: The opinions of students on the freedom of thought and expression were collected in the categories of "speech" and "participation". The opinions of students on such practices as hanging banners, distributing brochures and leaflets, printing newspapers or magazines, or wearing pins and armbands, etc. for educational purposes in schools were assessed in the categories of "yes", "conditional yes", and "no". Their opinions concerning the conduct of such practices for political purposes were addressed in the categories of "yes" and "no". Finally, the opinions of students on the imposition of short-term suspension, expulsion, or exclusion from formal education institutions on students for such practices were assessed in the categories of "consider the penalty dysfunctional" and "consider the penalty both functional and dysfunctional". The students taking part in the study have a conceptual knowledge of the freedom in question and a perception of the same as the right to speak. The study concluded that students mostly included the practices of hanging banners, distributing brochures and leaflets, printing newspapers or magazines, or wearing pins or armbands, etc., for educational purposes in the scope of the freedom of thought and expression, but excluded the conduct of the same practices for political purposes from the scope of said freedom. Finally, the majority of participants found the imposition of disciplinary penalties on students for the conduct of such practices as dysfunctional.

Conclusions and Recommendations: In line with these results, it may be suggested that disciplinary rules be consistent with the age and maturity of students. Furthermore, objectivity and compliance with international norms and democratic society in the limitations concerning the freedom of thought and expression are of great significance.

Keywords: student rights, disciplinary regulations, freedom of thought, freedom of expression

The freedom of thought is defined as an individual's right to have any thought or opinion, to be free from any pressure by reason thereof, not to be forced to disclose such thoughts and opinions, and not to be reprimanded or blamed for the disclosure thereof. In the statements used by Teziç $(1990,33)$, the freedom of thought is the possibility for an individual to choose or prepare their potential responses to any emerging problems and to adapt their individual or social acts to such responses. The right to the freedom of thought is a right that protects not the thought, but rather the owner of the thought. The freedom of expression is, alternatively, defined as the freedom of expressing any belief, opinion, attitude, or emotion in an amicable 
manner. This right protects the forms of thought and expression (Erdoğan, 2007, 1921; Bezanson, 2005, 239).

Article 19 of the Universal Declaration of Human Rights (1948) recognises the freedom of thought and expression for everyone. This freedom enables the individual to be entitled to be free from any disturbance by reason of their thoughts and to research, obtain, and disseminate their knowledge and thoughts in any manner possible without being limited by national borders. Article 10 of the European Convention on Human Rights (1950) (ECHR) states that "[e]veryone has the right to freedom of expression" and the European Court of Human Rights (ECtHR) considers this statement as a mandatory basis for democratic societies and as one of the most prominent conditions for progress and development for everyone (Kaboğlu, 2000, 110). Pursuant to the aforementioned statement, the freedom of thought and expression may not be restricted unconditionally. Any limitation must be consistent with the aims of protecting the individual or public interests or maintaining or restoring the independence and impartiality of the judiciary. Article 13 of the United Nations Convention on the Rights of the Child (1989) (UNCRC) prescribes in the first paragraph that every child shall have the right to express their thoughts freely; this right may be exercised, regardless of frontiers, either orally, in writing, in print, in the form of art, or through any other media of the child's choice. However, the second paragraph of Article 13 states that the exercise of this right may be subject to certain restrictions, but these shall only be such as are provided by law and are necessary for respect of the rights or reputations of others; or for the protection of national security or of public order or of public health or morals. Moreover, Article 14 of UNCRC prescribes an obligation for state parties to respect the right of the child to freedom of thought, conscience, and religion.

In Turkish law, the Constitution of 1982 regulates the freedom of thought and expression in Articles 25 and 26 and does not provide a distinction between adults, children, or students. The exercise of the said freedom may be restricted for the purposes of national security; public and safety; safeguarding the basic characteristics of the Republic and the indivisible integrity of the State with its territory and nation; preventing crime; punishing offenders; withholding information duly classified as a state secret; protecting the reputation, rights, and private or family life of others; protecting professional secrets as prescribed by laws or ensuring the proper functioning of the judiciary.

The child's/student's freedom of thought and expression has been discussed in literature. Some authors argue that children/students cannot be entitled to the freedom of thought and expression. As an example, Brighouse $(2002,51)$ asserts that children grow in a family environment where they are influenced greatly by their parents, and most of their knowledge comes from this impact. Although it is important for the development of children to be allowed to express themselves, it must be known that such expression does not fully reflect their own personalities and comments. Similarly, according to Etzioni $(2004,4)$, principles must be defined for the interpretation of the freedom of thought and expression, and such definitions must observe the best interests of the child. Etzioni's approach is essentially based on the child as a creature in need of protection and the importance of protecting them against any potential harm. In contrast, liberals also admit that the child must be protected against certain types of freedom of thought and expression. According to 
the liberal opinion held by Macleod $(2004,57)$, children have a specific, advanced interest based on the concept of moral personality. Every child must develop and utilise their moral power, which shapes the distinct and independent moral personalities of individuals. This argument leads to the emergence of the child's interest in obtaining information and developing independent opinions and thoughts. By reason of these interests, children are entitled to the freedom of thought and expression before adulthood.

The literature does not present a consensus concerning whether or not students are entitled to the freedom of thought and expression within the school environment. Especially in the Anglo-Saxon legal system, the scope and limits of freedom are defined in line with judicial decisions. However, there is no judicial decision in Turkey with respect to students' freedom of thought and expression. Instead, certain provisions of the Regulation on Secondary Education Institutions under the Ministry of National Education (e.g., 164/(1)/(j) and 164/(2)/(g)) dated 07.09.2013 includes restrictive arrangements on this matter. In parallel with the restrictive arrangements in the aforementioned regulation, Turkey unfortunately witnesses incidents that give rise to the impression that students' freedom of thought and expression is not addressed with a warm attitude. One of these incidents occurred in June 2014 when a best student, Işıtan Önder, received a reprimand after using the following statements in his graduation speech: "They have taken their right to life away. It is impossible for anyone not to think of Berkin Elvan or Ali Ismail Korkmaz. You must know that Ali Ismail Korkmaz, Berkin Elvan, and others will always be sitting on these desks." His best student status was taken away due to the penalty in question; consequently, he did not benefit from the best students' quota in the university entrance exam. Together with Eğitim-Sen Union, Işıtan Önder's family filed a suit at Kocaeli Administrative Court for the restitution of his best student status. The $2^{\text {nd }}$ Administrative Court of Izmit granted a stay of execution on the grounds that such a penalty could not be imposed. Nevertheless, the case has not yet been concluded (Hürriyet, Cumhuriyet, 2014).

The present study aims to identify how secondary school students consider the freedom of thought and expression within the context of disciplinary regulations and practices. In line with this objective, the study sought their opinions on the effects of disciplinary regulations and practices applied to secondary school students concerning their freedom of thought and expression, one of the fundamental rights and freedoms of children/students.

\section{Research Design}

\section{Method}

The present study aimed to identify how secondary school students consider the freedom of thought and expression within the context of disciplinary regulations and practices. Therefore, the study was designed and implemented in a phenomenological pattern that aimed to research the phenomena encountered in the form of incidents, experiences, perceptions, trends, concepts, and situations (Yildirim and Şimşek, 2005, 72).

Target Universe and Study Sample

The study's target universe was composed of students enrolled at general public and private secondary education institutions affiliated with the Ministry of National 
Education and located in the nine central districts of the province of Ankara, namely Altındağ, Çankaya, Etimesgut, Gölbaşı, Keçiören, Mamak, Pursaklar, Sincan, and Yenimahalle in the 2012-2013 Educational Year. The sample of the study was composed, in line with the maximum diversity sampling technique, of 15 students from amongst all students enrolled at general public and private secondary education institutions located in the central districts of the province of Ankara.

There are general public secondary education institutions in all central districts of the province of Ankara. However, there are no private secondary schools in Mamak and Sincan. The private secondary education institutions located in Gölbaşı and Keçiören did not permit interviews or failed to respond to the request for such permission. Therefore, the study was implemented at private secondary education institutions located only in Çankaya, Etimesgut, Pursaklar, and Yenimahalle. The private secondary education institution located in Altındağ was under the same ownership as the private secondary education institution located in Pursaklar and was therefore excluded from the study. As the number of general private secondary schools was too low when compared to the number of general public secondary schools, two more private schools from the district of Çankaya were also added to the scope of the study. Information regarding the codes, sexes, and localities of the participants is given in Table 1.

Table 1.

Expansion of the Codes Corresponding to Students in the Study Sample

\begin{tabular}{lllll}
\hline SK1k & public & 1. row & female & Keçiören. \\
\hline SK2k & public & 2. row & female & Çankaya \\
\hline SK3k & public & 3. row & female & Gölbaş1 \\
\hline SK4k & public & 4. row & female & Etimesgut \\
\hline SK5k & public & 5. row & female & Yenimahalle \\
\hline SK6e & public & 6. row & male & Altındağ \\
\hline SK7e & public & 7. row & male & Mamak \\
\hline SK8k & public & 8. row & female & Sincan \\
\hline SK9k & public & 9. row & female & Pursaklar \\
\hline SÖ1k & private & 1. row & female, & Çankaya \\
\hline SÖ2k & private & 2. row & female & Yenimahalle \\
\hline SÖ3e & private & 3. row & male & Etimesgut \\
\hline SÖ4k & private & 4. row & female & Pursaklar \\
\hline SÖ5e & private & 5. row & male & Gölbaş1 \\
\hline SÖ6e & private & 6. row & male & Çankaya
\end{tabular}

\section{Data Collection}

For the purposes of collecting data in line with the objective of the present study, a focus group meeting was held with a group of 7 teachers and administrators on 11.06.2012 with the aim of developing the statements/questions to be included in the 
student interview forms. The interview forms were prepared on the basis of the results of this focus group meeting and the "Reward and Discipline Regulation dated 19.01.2007 and No. 26408 for Secondary Education Institutions under the Ministry of National Education", which was in effect in this term (the second term of the 20122013 school year). Then, the interviews were submitted to an expert for review. ${ }^{1}$ The interview forms constitute the data collection tools for qualitative research (Punch, $2005,165)$. Interview forms allow for the systematic collection of information from a group of individuals with the same questions (Patton, 1987 trans. Kümbetoğlu, 2005, 75). The benefit of using interview forms lies in the most effective utilisation of the generally limited interview duration (Kümbetoğlu, 2005, 75). In this study, semistructured interview forms were preferred for data collection, as this method provides in-depth information regarding the subject at hand. The interview forms were finalised in line with the expert's opinions.

Permission was obtained from the Provincial Directorate of National Education (dated 12.04.2013 and No. 14588481/605.99/573725) for the application of the "Interview Form on Students' Opinions on the Reward and Discipline Regulation for Secondary Education Institutions under MoNE and its Implementation within the Context of Students' Fundamental Rights and Freedoms" to secondary school students.

Fifteen students were interviewed face-to-face in accordance with the semistructured interview forms. The interviews were conducted by the author. All participants were asked for permission for the sound recording of interviews; interviews with one student from a public secondary education institution and two students from private secondary education institutions were recorded on paper and the rest of the interviews were sound recorded. The majority of the interviews were conducted in the respective school environment; however, interviews with two students from private secondary education institutions were held in localities of their choosing outside their respective schools due to the start of the summer holiday.

\section{Data Analysis}

The sound recordings taken during interviews were transcribed. The transcribed or noted opinions of the participants were compiled into written text in the computer medium. Interviews thus compiled in written text were made subject to content analysis. Früh defined content analysis as "an empirical method providing a systematic and objective description of contextual formal characteristics of statements" (Früh, 2001 trans. Gökçe, 2006, 17). “Content analysis, as a method, aims to obtain certain findings on some dimensions and cross-sections of non-existent, or unknown social reality on the basis of the quantitative and qualitative dimensions of existing texts" (Gökçe, 2006, 20). In line with this aim, the first step to content

\footnotetext{
${ }^{1}$ Prof. Dr. Ali Balcı, Prof. Dr. İnayet Aydın, Prof. Dr. Nejla Kurul, Prof. Dr. Işıl Ünal, Prof. Dr. Meral Uysal, Prof. Dr. Ezel Tavşancıl, Prof. Dr. Hasan Hüseyin Aksoy Assoc. Prof. Dr. Şakir Çınkır, Ass. Prof. Dr. Nihan Demirkasımoğlu, Res. Ass. Dr. Saadet Kuru Çetin, Res. Ass. Dr. Fatih Kezer.
} 
analysis is defining an analysis category (main category) and subcategories (Strauss and Corbin, 1990 trans. Yıldırım and Şimşek, 2005, 227).

The analysis categories (themes) were defined, in parallel with the objective of the study, as the evaluation of disciplinary regulations and practices applied to students in secondary schools within the dimension of the "Freedom of Thought and Expression". Although this category was formed at the start of the research through the inductive method, the subcategories were identified during the analyses through the deductive method (Gökçe, 2006, 20). In accordance with the study problem, the first theme was associated with the first sub-problem, while the second, third, and fourth themes were associated with the second sub-problem. The author worked with his thesis supervisor in the codification of the dataset and reached a common codification by discussing the similarities and differences of all codifications and conceptualisations regarding the data.

The frequency and percentage values of the breakdown of participants' opinions were calculated and this breakdown was represented in tables. The interpretation of the participants' opinions also utilised the sentences/statements used by the participants themselves.

The analysis results obtained from the research were also codified by two experts ${ }^{2}$ with experience in quantitative research and previous academic research on fields relevant to the thesis subject with a view to testing the consensus. The interview transcripts of the study were codified primarily by the author. In addition to the author, two independent experts repeated these codifications. The results of codifications undertaken by different experts were compared through the formula developed by Miles and Huberman $(1994,278)$.

As a result of the codifications, the reliability degree was determined to be $79 \%$ with the first expert and $76 \%$ with the second expert. Houten and Hall $(1983,27)$ considers a reliability degree of $70 \%$ sufficient. Therefore, it was concluded that analyses were performed with a sufficient degree of reliability.

\section{Results}

Students' Opinions on Freedom of Thought and Expression

The students were asked to define the freedom of thought and expression and requested to explain this freedom. The students' opinions are given in Table 2.

\footnotetext{
2 Experts: Ass. Prof. Dr. Funda Nayır and S. İpek Aksoy Gülşen.
} 
Table 2.

Breakdown of Participants' Opinions on the Freedom of Thought and Expression

\begin{tabular}{|c|c|c|c|}
\hline $\begin{array}{l}\text { Study } \\
\text { Question }\end{array}$ & Sample Statements & Themes & $\mathbf{f}$ \\
\hline 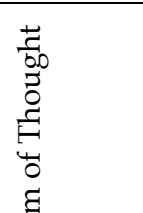 & $\begin{array}{l}\text { It is to express one's own opinions anywhere. } \\
\text { (SÖ3k; SÖ4k) } \\
\text { It is to express what one knows and wants to say } \\
\text { with ease and openness. (SK3k; SK7e; SÖ1k; } \\
\text { SÖ2k) }\end{array}$ & Speech & 11 \\
\hline 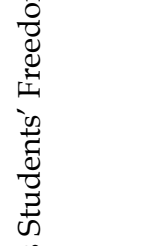 & $\begin{array}{l}\text { You can express your own thoughts without } \\
\text { breaching the line of respect, but you shouldn't } \\
\text { overlook the fact that you are talking to a teacher, } \\
\text { to an older person. You can thus express yourself } \\
\text { and explain your thoughts. (SK } 4 \mathrm{k} \text {; SK5e; SÖ8k; } \\
\text { SÖ9k) }\end{array}$ & & \\
\hline 当 & $\begin{array}{l}\text { I think, it means that I am free to draw pictures in } \\
\text { the classroom.... (SÖ6e) }\end{array}$ & & \\
\hline 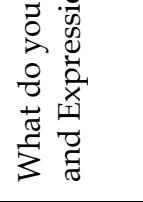 & $\begin{array}{l}\text { It is to express one's thoughts and opinions freely. } \\
\text { It is the ability to express your opinions and } \\
\text { suggestions to higher bodies and for them to take } \\
\text { these into consideration. ... (SK1k; SK2k; SK6e, } \\
\text { SÖ5e) }\end{array}$ & Participation & 4 \\
\hline
\end{tabular}

As can be seen in Table 2, the opinions of 11 students (6 public, 5 private) were addressed in the subcategory of "the right to speak", whereas the opinions of 4 students (3 public, 1 private) were included in the subcategory of "right to participate".

The students' opinions addressed in the subcategory of the right to speak were observed to define the freedom of thought and expression as the right to express one's own thoughts (SÖ3e, SÖ4k). Moreover, some students stated that the freedom of thought and expression is the right to speak freely and without any pressure (SK3k, SK7e, SÖ1k; SÖ2k). Some students also defined the freedom of thought and expression as the right to speak, but added that this freedom is restricted by a line of respect (SK4k, SK5k, SK8k, SK9k). In contrast, the majority of the students were seen to perceive expression as verbal expression. Nevertheless, SÖ6e stands out from other students in that they do not perceive expression only as verbal expression, but state that expression is also possible through painting. In addition, certain students stated that they perceived the freedom of thought and expression as their ability to express their own emotions and thoughts regarding any situation to adults and especially to school teachers and to be included in decision-making processes of relevance for themselves (SK1k, SK2k, SK6e, SÖ5e).

Opinions of Students on the Inclusion of such Practices as Hanging Banners, Distributing Brochures and Leaflets, Printing Newspapers or Magazines, or Wearing Pins And 
Armbands, etc. for Educational Purposes within the Scope of the Freedom of Thought and Expression

The opinions of students on the question as to whether such practices as hanging banners, distributing brochures and leaflets, printing newspapers or magazines, or wearing pins and armbands, etc. for educational purposes can be addressed within the scope of the freedom of thought and expression are given below (Table 3 ).

\section{Table 3.}

Breakdown of Students' Opinions on the Inclusion of such Practices as Hanging Banners, Distributing Brochures and Leaflets, Printing Newspapers or Magazines, or Wearing Pins and Armbands, etc. for Educational Purposes within the Scope of the Freedom of Thought and Expression

\begin{tabular}{|c|c|c|c|}
\hline $\begin{array}{l}\text { Study } \\
\text { Question }\end{array}$ & Sample Statements & Themes & $\mathbf{f}$ \\
\hline 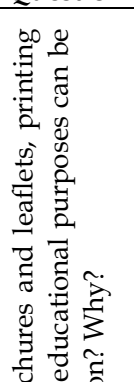 & $\begin{array}{l}\text { I think they can. In fact, students' opinions must be known to all and } \\
\text { if there is going to be a change in the education system, it should be } \\
\text { affected in line with these opinions. I believe that the student can } \\
\text { express their opinions on such matters. (SK1k) } \\
\text { Of course it can. This is expressing an opinion, showing an opinion. } \\
\text { Regardless of your opinion, you have the right to express your } \\
\text { opinion. To that end, we can also hang banners. Because you have } \\
\text { peers at school, who understand you and value your opinions. So, I } \\
\text { believe hanging a banner to disseminate your opinions to them is } \\
\text { quite right. (SÖ5e) (SK2k; SK7e; SK9k; SÖ1k; SÖ3e; SÖ4k; SÖ6e) }\end{array}$ & Yes & 9 \\
\hline 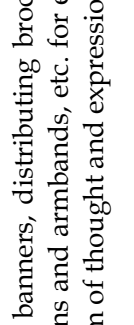 & $\begin{array}{l}\text { They should do that. To give us information on something, they can } \\
\text { use different ways to achieve higher goals in education. With different } \\
\text { elements, for example without any prohibitions, they can do } \\
\text { something properly within the framework of the law. (SK3k) } \\
\text { If it is indeed educational. Our principal keeps warning us already. If } \\
\text { there is nothing, no behaviour that can have a bad effect on us... but I } \\
\text { think it shouldn't be done without the approval of the principal. } \\
\text { (SK4k) }\end{array}$ & & \\
\hline 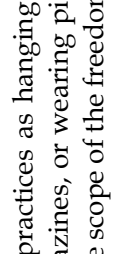 & $\begin{array}{l}\text { Last year, we had a collective mourning for a martyr. Then, they } \\
\text { distributed red ribbons to everyone. All students, including us, and } \\
\text { all teachers walked around with those. I think it should be done if it } \\
\text { does not disturb the peace or affect people adversely. .... (SK8k) } \\
\text { If educational, it can be. But if a student is going to do this, they } \\
\text { shouldn't go over the disciplinary limit. (SÖ2k) }\end{array}$ & $\begin{array}{c}\text { Conditional } \\
\text { Yes }\end{array}$ & 4 \\
\hline 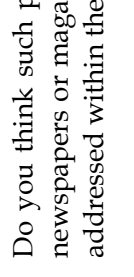 & $\begin{array}{l}\text { There can be opposite opinions. And that will not be good. It } \\
\text { shouldn't be in the school, but can be done outside of the school. } \\
\text { (SK5k) } \\
\text { I think these are all wrong behaviours. We have education at school } \\
\text { and we haven't reached } 18 \text { yet and we come to the school as students. } \\
\text { So once we are 18, we can do whatever we want outside, but it will } \\
\text { not be appropriate for us to do this within the school limits. (SK6e) }\end{array}$ & No & 2 \\
\hline
\end{tabular}


As can be seen in Table 3, the opinions of participating students were divided into the subcategories of "yes", "conditional yes" and "no" and assessed accordingly. In line with this assessment, the opinions of 10 students ( 5 public, 5 private) were addressed in the subcategory of "yes", while the opinions of 3 students ( 2 public, 1 private) were assessed in the subcategory of "conditional yes" and the opinions of 2 students from public schools were in the subcategory of "no".

The students whose opinions were addressed in the subcategory of "yes" saw such practices as hanging banners, distributing brochures and leaflets, printing newspapers or magazines, or wearing pins and armbands, etc. as a way to express and disclose their opinions as communication elements and considered them within the scope of the aforementioned freedom. These methods can be used to change the education system according to SK1k and to share opinions with peers for SÖ5e. The students' opinions addressed in the subcategory of "conditional yes" admit that the students can actually conduct the said activities for educational purposes, but add that such activities should not lead to negative consequences in short term. The negative consequences implied here were defined as in contradiction to laws (SK3k), misdirection (SK4k), disturbance of peace/affecting people (negatively) (SK8k), and disturbance/breach of discipline (SÖ2k). Considering the opinions assessed in the subcategory of "no", these students can be stated to consider such acts as hanging banners, distributing brochures and leaflets, printing newspapers or magazines, or wearing pins and armbands, etc. as problematic regardless of their purpose.

Breakdown of Students' Opinions on the Inclusion of such Practices as Hanging Banners, Distributing Brochures and Leaflets, Printing Newspapers or Magazines, or Wearing Pins And Armbands, etc. for Political Purposes within the Scope of the Freedom of Thought and Expression

The opinions of students on the question as to whether such practices as hanging banners, distributing brochures and leaflets, printing newspapers or magazines, or wearing pins and armbands, etc. for political purposes can be addressed within the scope of the freedom of thought and expression are given below (Table 4). 
Table 4.

Breakdown of Students' Opinions on the Inclusion of such Practices as Hanging Banners, Distributing Brochures and Leaflets, Printing Newspapers or Magazines, or Wearing Pins and Armbands, etc. for Political Purposes within the Scope of the Freedom of Thought and Expression

\begin{tabular}{|c|c|c|c|}
\hline $\begin{array}{r}\text { Study } \\
\text { Question }\end{array}$ & Sample Statements & Themes & f \\
\hline 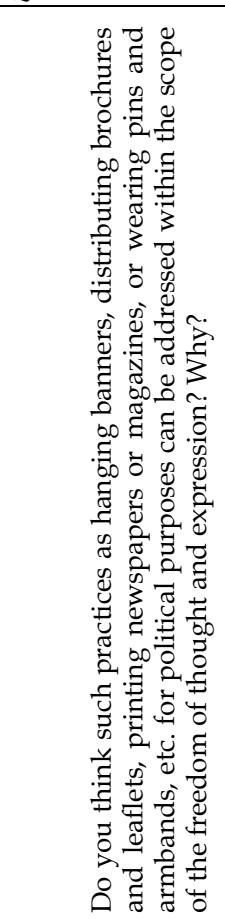 & $\begin{array}{l}\text {... I think these should be allowed, but there have to be certain } \\
\text { lines, red lines. This should not turn into a left or right matter. } \\
\text { Whenever I write something about workers, I am immediately } \\
\text { blacklisted, "oh, he is a leftist"... this shouldn't be the case. This is } \\
\text { actually an educational activity. My parents are both workers. I } \\
\text { believe that when I do this, it shouldn't be considered as political. } \\
\text { (SK7e) } \\
\text { I think they should be able to do this for political purposes, as } \\
\text { well. Because in fact, this is freedom of expression. They should be } \\
\text { able to express their opinions without someone stopping them and } \\
\text { forcing them to adopt a certain opinion, without targeting someone } \\
\text { else's right. (SÖ5e) (SK2k, SÖ1k) } \\
\text { No, it cannot. Then, there would be an environment of } \\
\text { arguments, more fights. So it would be more difficult to restore } \\
\text { order. (SK3k) (SK1k, SK5k, SÖ3e, SÖ4k) } \\
\text { If it is for political purposes, it is a crime in itself. Because an } \\
\text { individual of that age cannot have anything to do with politics. } \\
\text { (SK4k) }\end{array}$ & No & 11 \\
\hline
\end{tabular}

As can be seen in Table 4, the opinions of participating students were divided into the subcategories of "yes" and "no" and assessed accordingly. In line with this assessment, the opinions of 4 students (2 public, 2 private) were addressed in the subcategory of "yes", while the opinions of 11 students (7 public, 4 private) were assessed in the subcategory of "no". The students' opinions in the category of "yes" considered the said acts within the scope of the freedom of thought and expression, even if they were realised for political purposes. In the study, the definition of possible political purposes was left to the students to consider. Thus, SK7e emphasised that matters that appear to be political to certain people may actually have an educational aspect with their words regarding the educational and nonpolitical nature of statements on workers. Conversely, SÖ5e states that the consideration of the acts in question within the scope of the freedom of thought and expression are not problematic unless someone forcefully imposes their opinions on someone else. Considering the opinions in the subcategory of "no", we see that 
students do not consider the realisation of such acts for political purposes within the scope of the freedom of thought and expression. The justifications put forth by the students are young age, potential for arguments/conflicts, criminal aspect/prohibition, differences of opinion, going beyond the purposes of the school, and polarisation.

Opinions of Participants on the Imposition of Short-Term Suspension, Expulsion, or Exclusion from Formal Education Institutions as Penalties due to such Acts as Hanging Banners, Distributing Brochures and Leaflets, Printing Newspapers or Magazines, or Wearing Pins and Armbands, etc. at School

The opinions of participants on the imposition of short-term suspension, expulsion, or exclusion from formal education institutions as penalties due to such acts as hanging banners, distributing brochures and leaflets, printing newspapers or magazines, or wearing pins and armbands, etc. at school are addressed below (Table5).

Table 5.

Breakdown of Opinions of Participants on the Imposition of Disciplinary Penalties due to such Acts as Hanging Banners, Distributing Brochures and Leaflets, Printing Newspapers or Magazines, or Wearing Pins and Armbands, etc. at School

\begin{tabular}{|c|c|c|c|}
\hline $\begin{array}{r}\text { Study } \\
\text { Question }\end{array}$ & Sample Statements & Themes & f \\
\hline \multirow[t]{2}{*}{ 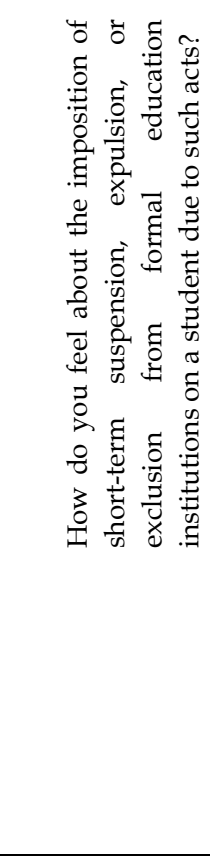 } & $\begin{array}{l}\text { I don't think that such penalties will be very effective on } \\
\text { students. Because when you impose a penalty, the problem is not } \\
\text { solved at its root. Instead, the student can be warned not to repeat the } \\
\text { same act or if he doesn't know that act is wrong, such acts should be } \\
\text { explained to students at the beginning so that they do not act in that } \\
\text { wrong way. So they should exercise the freedom of thought in any } \\
\text { way except for political purposes. (SK1k) (SK8k, SK2k) } \\
\text { If we are living in a free place, the student should be able to } \\
\text { express their emotions and opinions. He should not be penalised for } \\
\text { this. If he did something wrong, he should be reprimanded. (SK3k) } \\
\text { (SÖ3e, SÖ5e, SÖ6e) } \\
\text { I am absolutely against this. No student should be excluded from } \\
\text { his environment due to his opinions. In fact, this is where the freedom } \\
\text { of thought is restricted. (SK9k) (SK5k, SK7e, SÖ1k) }\end{array}$ & $\begin{array}{c}\text { Consider } \\
\text { penalties } \\
\text { dysfunctional }\end{array}$ & 11 \\
\hline & $\begin{array}{l}\text { Actually, a reprimand... may be normal. But I think he doesn't } \\
\text { have to be expelled or sent to an open high school. He does it once. } \\
\text {...But he won't do it again after a reprimand. (SÖ2k) } \\
\text {... I think suspension should not be an option, but firstly a } \\
\text { reprimand should be issued. If the reprimand does not work, then } \\
\text { other penalties can be considered. I think, suspension should be the } \\
\text { last resort. (SK } 4 \mathrm{k})(\mathrm{SK} 6 \mathrm{e}, \mathrm{SÖ} 4 \mathrm{k})\end{array}$ & $\begin{array}{c}\text { Consider } \\
\text { penalties } \\
\text { both } \\
\text { functional } \\
\text { and } \\
\text { dysfunctional }\end{array}$ & 4 \\
\hline
\end{tabular}


As can be seen in Table 5, the students' opinions were assessed within the subcategories of "consider penalties dysfunctional" and "consider penalties both functional and dysfunctional". In line with this assessment, the opinions of 11 students (7 public, 4 private) were addressed in the subcategory of "consider penalties dysfunctional", while the opinions of 4 students ( 2 public, 2 private) were assessed in the subcategory of "consider penalties both functional and dysfunctional".

With respect to the opinions addressed in the subcategory of "consider penalties dysfunctional", students do not consider the imposition of penalties on students for exercising their freedom of thought and expression and argue that the freedom of thought and expression cannot be fully exercised due to such penalties. In addition, the students whose opinions were assessed in this subcategory think that the imposition of penalties due to the exercise of the freedom of thought and expression has a negative effect on their freedoms, but it is not appropriate for them to exercise this freedom in such a manner as to reflect political elements. In terms of the opinions addressed in the subcategory of "consider penalties both functional and dysfunctional", the students do not consider the imposition of penalties for the said acts as problematic, but are of the opinion that the current penalties are too heavy and less substantial penalties should be imposed, such as warnings and reprimands.

\section{Discussion and Conclusion}

The present study explained how the students' freedom of thought and expression is regulated in national and international legislation, the current situation in various legal systems, and how students perceive the freedom in question. According to the study results, the students taking part in the study have a conceptual knowledge of the freedom in question and a perception of the same as the right to speak. The study concluded that students mostly included the practices of hanging banners, distributing brochures and leaflets, printing newspapers or magazines, or wearing pins or armbands, etc., for educational purposes in the scope of the freedom of thought and expression, but excluded the conduct of the same practices for political purposes from the scope of said freedom. Finally, the majority of participants found the imposition of disciplinary penalties on students for the conduct of such practices as dysfunctional (Lobel, Heckel and Avenarius, 2000, 548)

Whether or not the students have the freedom of thought and expression in schools has been discussed in legal literature. Considering these discussions, there are two approaches in the Anglo-Saxon law: i.e., restrictive and liberal. The restrictive approach argues that student freedom of thought and expression at school is not equal to adult freedom of thought and freedom. In fact, the school system pursues the sole goal of educating students. Therefore, any expression may be restricted by the school administration if it contradicts the goals of the school or the pedagogical duties of schools (Landwehr, 2000, 393). Alternatively, the liberal approach holds schools as institutions where students find openings to express their 
opinions by taking the floor in classrooms or through different means in school environments (e.g., specialised community activities, school newspaper, etc.). As with the other members of the society, students feel entitled to the freedom of thought and expression and it is admitted that these freedoms are maintained also within the physical borders of a school. Thus, the school administration may not impose restrictions that will eliminate students' freedom of expression, even if it does not agree with some of the students' opinions and/or the methods they use to express the same. The administration may restrict the freedom of thought and expression to attain certain goals - those consistent with the requirements of a democratic society and pursue the realisation of the common interests of the public and the proportionality of the restrictions applied; the goals pursued must be observed in this process (Imber and Geel, 2005, 71).

Similarly to the liberal approach in the Anglo-Saxon system, the German Law (pursuant to Article 5(1) of the Basic Law for the Federal Republic of Germany, Grundgesetz, GG) admits that students are entitled to the freedom of thought and expression in any relationship they establish with the school. German Law prescribes training students with the skills needed to have a perspective and advocate various theses on any matter expressly as one of the duties of schools and considers any school that hinders students' freedom of thought and personal development to be in contradiction with its educational duties. Nevertheless, the freedom of thought and expression granted to students is not free from restrictions; the restrictions specified in provisions in general laws are aimed at protecting the youth, human reputation, and dignity (Article 5(2) of the Constitution). The general laws not only define the duties of schools, but also the restrictions to the freedom of thought and expression. The general laws are interpreted in light of fundamental rights. The duties of schools are specified in general laws, as well as school laws where educational duties are concretised on the basis of their designations in national and state laws. However, students are not allowed to talk about matters other than subjects at hand or to talk during classes within the scope of the freedom of thought and expression. The teacher is in charge of avoiding any such disturbances.

The general objectives of education in Turkey are stipulated in Article 2 of the Basic Education Law No. 1739. According to paragraph 2, one of the objectives to be pursued by education is to "train students as constructive, creative and efficient individuals with personalities and characters developed in a balanced and healthy manner in terms of physical, mental, moral, spiritual and emotional aspects; equipped with the power of free and scientific thinking and a wide outlook of the world; approaching human rights with respect and valuing personalities and entrepreneurship; and having a sense of responsibility towards the society". Setting off from this objective, it is possible to assume that students are entitled to the freedom of thought and expression in order for them to have "the power of free and scientific thinking and a wide outlook of the world". Conversely, the Constitution of 1982 strengthens this assumption in that it regulates the freedom of thought and expression without a distinction between adults and children or students in Articles 
25 and 26. The freedom in question may only be restricted for the purposes defined in the Constitution and in general laws.

Judicial decisions regarding students' freedom of thought and expression in Turkey mostly concern students enrolled in higher education institutions. However, these students are excluded from the scope of the present study. In any case, it must be noted here that the $8^{\text {th }}$ Chamber of the Council of State cancelled the amendment to the "Student Discipline Regulation for Higher Education Institutions" that had added the act of "distributing leaflets" to the list of disciplinary offences to be reprimanded on the grounds that such an amendment constituted a breach of the freedom of thought and expression (Sondurakhaber, 2014).

In contrast, relevant judicial decisions can be seen in the USA, where educational law is quite advanced. The United States Supreme Court handled the presence or absence of students' freedom of expression and the potential situations giving rise to this freedom for the first time with its decision in Tinker $v$. Des Moines Independent Community School District in 1969. This decision resulted in the rule known as the Tinker Test. According to this rule, the school administration may only prohibit an expressed statement if such statement may cause a problem, lead to a material or substantial fault in the functioning of the school, or breach someone else's rights. The most important benefit of this test is that the school administration cannot penalise or prohibit any opinion merely on the grounds that it does not agree with the expression or solely on the grounds of a general fear of potential fault in the school system. Nevertheless, reasonable restrictions may be imposed by the school management with relation to the time, place, and manner of expression on the condition that such restriction(s) is required for the pursuit of educational goals. As an example, it is reasonable to prohibit students from talking politics during a maths class, but it is not reasonable to prohibit them from talking politics during lunch, i.e. at times where they can engage in free discussions regarding their own choices. However, for certain there are exceptional conditions.

Contrary to Turkey, the political opinions of students are welcomed within schools in Europe and the USA. As an example, according to Swiss and Austrian law, students can express their political opinions, publish them in the school newspaper, and form political organisations and assemblies even within schools. However, these rights may be restricted by lawmakers for educational purposes in cases where, for instance, militant student groups or political propaganda are observed. Richter (1990, 132) suggests that practitioners of educational law and school administrators find a common ground between the political impartiality of schools and political rights of students. Similarly, German Law admits the possibility of wearing pins and badges to express opinions and prescribes that the right to express opinions in this manner is under legal protection. Students can defend their opinions on social criticism and social morality in an excessive and influential manner (recht auf jugendlichen Überschwang). However, students cannot jeopardise the performance of educational duties and, specifically, cannot disturb the peace in schools. Yet, a student does not exceed the limits of the freedom of expression by merely wearing a badge (Avenarius, 2001, 105). Conversely, in the Texas v. Johanson case, the Supreme Court 
ruled that students' clothing, hairstyle, rosaries, or badges, etc. can be considered within the scope of the freedom of thought and expression, whereas words of obscenity, threat, hostility, or insult cannot be addressed within the scope of the freedom of thought and expression and cannot benefit from legal protection (Imber and Geel, 2005, 51).

\section{Suggestions}

In order for students' freedom of thought and expression to be under legal guarantees, students must be primarily given information about the content and limits of the freedom in question. With respect to the specific statements of students that can be addressed within the scope of the freedom of thought and expression, the definition of such statements through legal arrangements is of great importance, as the Turkish legal system lacks a sufficient body of case-law in this field. The consistency of the legal arrangement in question with the age and maturity of students is also an important aspect. When we consider the rules in effect for the penalisation of disturbing behaviours of students, we see that students are addressed almost as adults. In fact, disciplinary rules for students must not be structured with “concepts and institutions from the adults' world" (Ümit Atılgan, 2007, 289).

Then again, the exercise of the freedom of thought and expression by students without any prior permission from an institution is not subject to penalties in the legal systems of foreign countries. Indeed, such acts are penalised only if they have exceeded certain limits predefined by law or following an assessment to be conducted in line with the legal facts of individual cases. However, students in Turkey can exercise their freedom of thought and expression only by obtaining permission from the school management or within the scope of specialised communities. The permission in question must be eliminated as it constitutes an obstacle to the effective exercise of the freedom of thought and expression and is replaced by criteria that appropriately restrict this freedom in an objective manner that is consistent with international norms and the requirements of a democratic society.

Finally, it is important to raise awareness among students in their exercise and protection of fundamental rights and freedoms with respect to the fact that they will be entitled to vote at the age of 18 and may even be involved in the executive activities of the state as public personnel or in legislative activities as elected officials in the national assembly. 


\section{References}

Avenarius H. (2001). Einführung in das schulrecht [Introduction to school law]. Darmstadt: Wissenschaftliche Buchgesellschaft.

Basic Law for the Federal Republic of Germany, Grundgesetz, GG, 23 May., 1949, art.5. Retrieved April 20, 2014 from https://www.btg-bestellservice.de/pdf/80201000.pdf

Best student status in Danger (2014, 18 June) Hürriyet. Retrieved June 19, 2014 from http:/ / www.hurriyet.com.tr/gundem/26627592.asp

Bezanson P. B. (1995). Institutional Speech, Iwo Law Review, 80, 735-824.

Brighouse H. (2002). What Rights (if any) Do Children Have?, In D. Archard and C. M. Macleod (Eds) The moral and political status of children (pp. 31-52). Oxford University Press: Oxford.

Constitution of the Republich of Turkey, 1982, no. 2708, P.2, C.2, art.25, 26. Retrieved April 20, 2014 from http://global.tbmm.gov.tr/docs/constitution_en.pdf

Erdoğan M. (2007). İfade Özgürlüğü ve Sınırları [Freedom of Thoughts and Limitations]. T. Bora (Eds), Iffade özgürlüğü ilkeler ve Türkiye [Freedom of thoughts: principles and Turkey].İstanbul: İletişim Yayınları.

European Convention on Human Right, 4 Dec., 1950. Retrieved April 20, 2014 from http://www.echr.coe.int/Documents/Convention_ENG.pdf

Etzioni A. (2004). On Protecting Children From Speech, Chicago-Kent Law Review, 79(3), 3-53.

Good news for Işıtan Önder (2014, 17 July) Cumhuriyet. Retrieved July 18, 2014 from http://www.cumhuriyet.com.tr/haber/turkiye/95301/Okul_birinciligi_eli nden_alinan_Isitan_Onder_e_iyi_haber.html

Gökçe O. (2006). İçerik analizi kuramsal ve pratik bilgiler [Content analysis: theoritical and pratical information]. Ankara: Siyasal Kitabevi.

Houten V. R., Hall R.V. (1983). The measurement of behaviour: behaviour modification, USA.

Imber M., Geel T. V. (2005). A Teacher's guide to education law. Roudledge: United States of America.

Kaboğlu İ.Ö. (2000). Düşünce özgürlüğü [Freedom of thoughts] K. Tankuter (eds), Insan hakları [Human rights]. İstanbul: YKY Yayınları.

Kümbetoğlu B. (2005). Sosyolojide ve antropolojide niteliksel yöntem ve araştırma [Qualitative method and research in sociology and anthropology] Ankara: Bağlam Yayıncilık. 
Landwehr, A. (2000). A Student's Right to Freedom of Speech in Light of Henerey v. City of St. Charles School District, Journal of Law and Education, 29, 393397.

Lobel H.C., Heckel H., Avenarius H. (2000). Schulrechtskunde [Information of Right to Education]. Neuwied: Luchterhand.

Macleod C. M. (2004). A Liberal Theory of Freedom of Expression For Children, Chicago-Kent Law Review, 79 (3), 55-82.

Miles M. B., Huberman A. M. (1994). Qualitative data anaylsis, USA:Sage Publications.

Punch K. F. (2005). Sosyal araştırmalara giriş, nicel ve nitel yaklaşımlar[Introduction to social researches, quantitative and qualitative approaches] (Translated by D. Bayrak, H.B. Arslan, Z. Akyüz), Ankara: Siyasal Kitabevi.

Regulation of Secondary Education Institutions, published in official journal on 07.09.2013, no. 28758, art. 164. Retrieved April 21, 2014 from http://mevzuat.meb.gov.tr/html/ortaogrkurumyon_0/ortaogrkuryon_1.ht $\mathrm{ml}$

Reward and Discipline Regulation, published in official journal on 19.01.2007, no. 26408, art. 12. Retrieved April 21, 2014 from http://mebk12.meb.gov.tr/meb_iys_dosyalar/16/01/964259/dosyalar/201 3_03/08023339_odulvedisiplinyonetmeligi.pdf

Richter I. (1990). West Germany, Switzerland and Austria, In I. Birch, I. Richter (Eds.), Comparative School Law (p.119-139).

Sondurak (2014). Retrieved from http://www.sondurakhaber.com/haber-10000ogrenci-disiplin-yonetmeliginde-yapilan-degisikliklerin-yurutmesidurduruldu.html

Student Discipline Regulation for Higher Education Institutions, published in official journal on 18.08.2012, no. 28388. Retrieved April 21, 2014 from http://www.yok.gov.tr/web/guest/icerik//journal_content/56_INSTAN CE_rEHF8BIsfYRx/10279/17960

Texas v. Johnson, 491 U.S. 397 (1989).

Teziç E. (1990). Türkiye'de siyasal düşünce ve örgütlenme özgürlüğü [Freedom of political thoughts and organization in Turkey]. Anayasa Yargist Dergisi, 7, 2946.

Tinker v. Des Moines Independent Community School District, 393 U.S. 503 (1969).

United Nations (1948/2009). Universal declaration of human rights. Retrieved April 20, 2014 from http://www.un.org/en/documents/udhr/inde 
United Nations Convention on the Rights of the Child, 20 Nov., 1989. Retrieved April 20, 2014 from http://www.ohchr.org/en/professionalinterest/pages/crc.aspx

Ümit Atılgan E. (2007). Mekandan imkana: çocuk suçluluğunun habitusu ceza ehliyeti ilişkisi [From urban to opportunity: the habitus of juvenile delinquency]. Ankara: Ankara Barosu.

Yıldırım A., Şimşek H. (2005). Sosyal bilimlerde nicel araştırma yöntemleri [Methods of Quantitative Research in Social Sciences].Ankara: Seçkin Yayınları.

\title{
Orta öğretim Öğrencilerinin Disiplin Düzenleme ve Uygulamalarının Düşünce ve İfade Özgürlüğüne Etkisi Hakkındaki Görüşleri
}

\author{
Atıf: \\ Taşkın P. (2014). Opinions of Secondary School Students on the Effects of \\ Disciplinary Regulations and Practices on the Freedom of Thought and \\ Expression. Eurasian Journal of Educational Research, 57, 51-72 \\ http://dx.doi.org/10.14689/ejer.2014.57.5
}

\section{Özet}

Problem Durumu: Okullarda öğrencilerin sorunsuz ve eksiksiz biçimde eğitim öğretim faaliyetlerden yararlanabilmeleri için disiplin kurallarına ihtiyaç duyulması kaçınılmazdır. Türkiye'de öğrencilerin okullarda uymaları gereken disiplin kuralları, her eğitim basamağına özel olarak hazırlanan yönetmelikle düzenlenmektedir. Ortaöğretim Kurumları Yönetmeliği'nde yer alan disipline ilişkin kurallar, kınama, kısa süreli uzaklaştırma, okul değiştirme ya da örgün eğitim kurumları dışına çıkarma şeklide cezalar öngörmektedir. Disiplini bozucu eylemin karşılığında hangi cezanın öngörüldüğü, yönetmelikte tek tek sayılmakla birlikte, öngörülemeyen fiiller için de benzer eylemlerde bulunanlara uygun disiplin cezası uygulanacağı yönetmelikte düzenlenmiştir. Öte yandan, çeşitli ulusal veya uluslararası hukuki düzenlemelerle (Anayasa, ilgili Kanunlar, Birleşmiş Milletler Çocuk Haklarına Dair Sözleşme gibi), çocuklara temel hak ve özgürlükler tanınmıştır. 18 yaşını doldurmamış öğrenciler de ilgili hükümler sayesinde temel hak ve özgürlüklere sahiptir. Bunlardan birisi düşünce ve ifade özgürlüğüdür. Ancak söz konusu özgürlük mutlak değildir; çeşitli sinırlar dahilinde kullanılabilir. Fakat çocukların/öğrencilerin okullarda düşünce ve ifade özgürlüğüne sahip olup olmadıkları ve bu özgürlüğün sinırlarının ne olduğu öğretide tartışmalıdır. Bu tartışmalar, sadece farklı ülkelerin Anayasa, kanun gibi hukuki metinleriyle değil, çeşitli yargı kararlarıyla da (Tinker v. Des Moines Independent Community School District ve Texas v. Johanson gibi) 
şekillenmektedir. Bununla birlikte Türkiye'de çocukların/öğrencilerin düşünce ve ifade özgürlüğü konusu, toplumsal gelişmeler 1şığında ele alınması gereken önemli bir konudur. Türkiye'de çocukların/öğrencilerin düşünce ve ifade özgürlüğüne ilişkin özel düzenlemeler bulunmamakta, söz konusu özgürlüğün kapsamı ve sınırları Anayasa ve ilgili kanun gibi genel düzenlemelerle yapılmaktadır. Öte yandan bahsi geçen özgürlükten çocukların/öğrencilerin hangi sınırlar dahilinde yararlanabileceğini yorumlayan Türk mahkeme kararlarına rastlamak güçtür. Çünkü disiplin düzenleme ve uygulamalarından doğan davalarda çocukların/öğrencilerin sahip oldukları temel hak ve özgürlükler ve sınırları konusunda özgürlükçü değerlendirmeler nadirdir. Bu tür yorumlar için, söz konusu temel hakların ve özgürlüklerin süjesi konumunda olan öğrencilerin konuyla ilgili görüşlerine yer verilmesinin kanun koyucuları, hukuki düzenlemeyi uygulayıcı konumunda olan eğitim yöneticileri ve öğretmenleri ve son olarak uyuşmazlıkları çözen yargıçları olumlu etkileyebileceğine inanılmaktadır. Böylelikle, bu çalışmanın problemini, disiplin düzenleme ve uygulamalarının öğrencilerin düşünce ve ifade özgürlüğüne etkisinin, öğrenci görüşleri doğrultusunda değerlendirilmesi oluşturmaktadır.

Araştırmanın Amacı: Orta öğretim okullarında okuyan öğrencilerin disiplin düzenleme ve uygulamaları bağlamında, düşünce ve ifade özgürlüğünü nasıl değerlendirdiklerini saptamaktır.

Araştırmanın Yöntemi: Araştırma, olgubilim deseninde tasarlanmış ve yürütülmüş bir nitel araştırmadır. Araştırmanın çalışma grubu, maksimum çeşitlilik örneklemesi tekniği doğrultusunda, Ankara ili merkez ilçelerindeki genel kamu ve özel ortaöğretim kurumlarında bulunan tüm öğrencilerden, araştırmaya katılmaya gönüllü 15 öğrenciden oluşmuştur. Çalışma grubunda bulunan 15 öğrenciyle yarı yapılandırılmış görüşme formları doğrultusunda yüz yüze görüşmeler yapılmıştır. Görüşme formları, Milli Eğitim Bakanlığı Ortaöğretim Kurumları Yönetmeliği ile ilgili literatür bir arada ele alınarak oluşturulmuştur. Yazılı metin haline getirilen görüşmeler içerik analizi yöntemi ile analiz edilmiştir Çözümleme kategorileri (temalar), araştırmanın amacına paralel olarak, ortaöğretim kurumlarında öğrencilerle ilgili disiplin düzenleme ve uygulamalarının, "Düşünce ve İfade Özgürlüğü" boyutunda değerlendirilmesi olarak alınmıştır. Alt kategoriler analizler sırasında tümevarım yöntemiyle belirlenmiştir

Araştırmanın Bulguları: Öğrencilerin düşünce ve ifade özgürlüğüne ilişkin görüşleri, "söz söyleme" ve "katılım" kategorilerinde toplanmıştır. Öğrencilerin okulda eğitsel amaçlarla, pankart asılması, broşür, bildiri dağıtılması; gazete veya dergi çıkartılması, arma, kol bandı vs. takılması hakkındaki görüşleri, "evet", "şartlı evet" ve "hayır" kategorilerinde incelenmiştir. Sayılan eylemlerin siyasal amaçlarla yapılmasına ilişkin görüşleri, "evet" ve "hayır" kategorilerinde ele alınmıştır. Son olarak, bu eylemleri yaptığı için öğrenciye kısa süreli uzaklaştırma, tasdikname ile uzaklaştırma veya örgün eğitim dışına çıkarma cezası verilmesine ilişkin öğrencilerin görüşleri, "cezayı işlevsiz bulma" ve "hem işlevsiz hem işlevsel bulma" kategorilerinde incelenmiştir. 
Araştırmanın Sonuçları ve Öneriler: Araştırmaya katılan öğrencilerin düşünce ve ifade özgürlüğünü kavramsal olarak bildikleri ve çoğunlukla söz söyleme hakkı olarak algıladıkları söylenebilir. Öğrencilerin okulda eğitsel amaçlarla pankart asmalarını, broşür, bildiri dağıtmalarını, gazete veya dergi çıkartmalarını, arma, kol bandı vs. takmalarını, katılımcıların çoğunlukla düşünce ve ifade özgürlüğü kapsamında değerlendirdikleri belirlenmiştir. Ancak sayılan eylemlerin siyasal amaçlarla yapılmasını yaş küçüklüğü, tartışma/çatışmaya yol açması, suç/yasak oluşturması, görüşlerin farklı olması, okulun amaçlarının dışına çıkılması, gruplaşma gerekçeleriyle bahsedilen özgürlük kapsamında değerlendirmedikleri sonucuna ulaşılmıştır. Son olarak, söz konusu eylemleri yapmaları nedeniyle öğrencilerin çeşitli disiplin cezalarını almalarını, katılımcılar çoğunlukla işlevsiz bulmuşlardır. Verilen cezaların ă̆ır olması nedeniyle öğrenciler cezanın amacına ulaşmayacağını ve kınama, uyarma gibi daha hafif cezalar verilmesinin uygun olacağını ifade etmişlerdir. Bu sonuçlar doğrultusunda, disiplin kurallarının öğrencinin yaşına ve olgunluk düzeyine uygun, açık ve anlaşılır olması gerektiği önerilebilir. Disiplin kurallarının öğrencinin temel hak ve özgürlüklerini fiilen kullanılamaz hale getirmemesi gerekir. Düşünce ve ifade özgürlüğüne yönelik sınırlamaların objektif olması önemlidir; aksi takdirde öğrencilerin sahip oldukları hakları kullandıkları için cezalandırılması gibi hakkaniyete uygun olmayan bir sonuç doğabilir. Son olarak söz konusu özgürlüğün etkin biçimde kullanılabilmesi için, düşünce ve ifade özgürlüğüne yönelik sınırlamaların objektif olması ve uluslararası normlara ve demokratik toplum düzenine uygun olması da önem arz eder. Aksi takdirde keyfilik sonucu doğabileceği gibi, toplumsal koşullanmalar nedeniyle temel hak ve özgürlüklerin etkili biçimde kullanılması sağlanamayabilir. 
